This is the version of the chapter accepted for publication in Alford, William, Cohen, Jerome and Lo, Chang-fa, (eds.), Taiwan and International Human Rights: A Story of Transformation. Singapore: Springer, pp. 155-172. (Economics, Law, and Institutions in Asia Pacific)

https://doi.org/10.1007/978-981-13-0350-0_10

Accepted version downloaded from SOAS Research Online: http://eprints.soas.ac.uk/24511

\title{
The Control Yuan and Human Rights in Taiwan: Towards the Development of a National Human Rights Institution?
}

\author{
Dr. Ernest Caldwell (康佩理) ${ }^{*}$
}

\begin{abstract}
"Taiwan has not yet decided whether it should establish a completely independent [human rights] institution or to subordinate it to either the Presidential Office or the Control Yuan."
\end{abstract}

(International Group of Independent Experts 2017)

\section{Introduction}

In 2013, the Taiwanese government underwent its first ICCPR and ICESCR compliance review by an independent group of international experts in the field of human rights. Following that review, the group recommended, inter alia, that the government set a specific time frame 'for the establishment of an independent national human rights commission in accordance with the Paris Principles as a priority objective.' (2013, para. 8 and 9) However, by the time of the second periodic review, conducted in January 2017 , the group of experts still noted that despite their previous recommendation, Taiwan had yet to establish a National Human Rights Institution (hereafter, NHRI) that complies with the Paris Principles. ${ }^{1}$ There are, of course, several reasons for the delay, but one primary reason is hinted at in the opening quotation of this chapter. What type of NHRI should Taiwan establish? The Paris Principles, which

\footnotetext{
* [BA, MA, LLM, PhD] Lecturer in Laws of China and Taiwan; School of Law and Centre for Taiwan Studies; SOAS, University of London. Email: ec24@soas.ac.uk

1 The 'Principles Relating to the Status and Function of National Institutions for the Protection and Promotion of Human Rights' (hereafter, Paris Principles) were drafted in 1991 by existing NHRIs and subsequently endorsed by the Commission on Human Rights in 1992 and the United Nations General Assembly in 1993. At present, they are internationally accepted as "the template against which to assess an NHRI". (De Beco and Murray 2015)
} 
have become a set of international standards for establishing NHRIs, are written in broad and general language. Furthermore, although the Paris Principles enumerate specific functions and mandates, they do not define a NHRI by any specific structural form. Indeed, the list of NHRIs internationally accredited by the Global Alliance for National Human Rights Institutions (hereafter, GANHRI) ${ }^{2}$ evidences a variety of acceptable institutional structures ranging from single member ombudsman offices to multi-member independent commissions. Therefore, in creating its own NHRI, Taiwan can choose from several possible existing NHRI structures used in other jurisdictions or it can produce something unique, so long as the established institution conforms to the international norms provided by the Paris Principles.

In Taiwan, there has been little debate over whether the country needs a dedicated human rights institution or commission. However, the primary issue precluding the establishment of an NHRI to date has been the fact that the Taiwanese have yet to determine what type of NHRI best suits Taiwan's political and social landscape (Wei 2012; Liao 2001; Huang S. (黄嵩立) 2014; Li 2012). As the initial quote shows, Taiwan is currently confronted by three options for the establishment of an NHRI: a fully independent commission, a quasi-independent commission housed in the Presidential Office, or a commission housed within a reformed and repurposed Control Yuan. These options are not necessarily new and have been debated for decades (Su 2002; Liao 2001). Most recently in a forum of NHRI experts held at the Legislative Yuan

\footnotetext{
${ }^{2}$ GANHRI, formerly known as the International Coordination Committee of National Institutions for the Promotion and Protection of Human Rights, has a Sub-committee on Accreditation (SCA). The SCA received applications for accreditation from NHRIs and provides a ranking of "A"-fully compliant, "B"partially compliant, or " $\mathrm{C}$ "- not compliant. This accreditation opens the door for various levels of participation in regional and UN supported human rights events. Taiwan has not yet submitted an institutional application for accreditation. For more information, visit: http://nhri.ohchr.org/
} 
in Taipei from 24-28 July 2017, these three options were considered at length. In the end, the forum panelists recommended that of the three possible options for establishing a NHRI for Taiwan the 're-branding' and transformation of the Control Yuan into a NHRI would be the most logical and cost-efficient option (Covenants Watch (人權 公約施行監督聯盟) 2017). In this chapter I examine the Control Yuan's relationship to human rights in Taiwan, and then critically analyze the potential to transform the institution into a NHRI fully compliant with the Paris Principles. I argue that although the Control Yuan certainly appears to be the most logical choice, its successful transformation is by no means an easy task. Many of the alterations necessary to meet the compliance standards of the international human rights community require significant constitutional revisions, changes to legislation, and a bolstering of the Control Yuan's public image. Due to the procedural requirements for making constitutional changes and legislative revisions, such alterations, however minor, would require a great deal of cross-party cooperation as well as immense public support. It is hoped that the present chapter complements other chapters on NHRIs in this volume written by professors Mab Huang and Liao Fu-te.

This chapter consists of five sections. Following this introduction, Section II examines the Control Yuan as a constitutional branch of the national government and further considers the historical development of its role in the protection and promotion of human rights in Taiwan. Section III then provides a basic assessment of the Control Yuan vis-à-vis the Paris Principles. Section IV turns to the steps highlighted by the recent forum participants necessary to transform the Control Yuan into a NHRI capable of receiving international accreditation, and critically assesses the feasibility of 
executing such changes. Finally, Section $V$ concludes the chapter by considering the ongoing debates over the future of the Control Yuan and the potential impact of that future on human rights development and protection in Taiwan.

\section{The Control Yuan and Human Rights: A Very Brief History}

Those unfamiliar with the constitutional structure of Taiwan's national government may be forgiven for asking, what is the Control Yuan? or what is the Control Yuan's relationship to human rights? While the vast majority of the world's constitutions divide government power via a tripartite government structure attributed to Montesquieu, the 1947 Republic of China constitution (hereafter, 1947 ROC constitution) divides government power amongst five distinct branches of government (Vile 1998). Three of these branches correspond to the archetypical Executive, Legislative, and Judicial branches common throughout the world; however, two additional branches—drawing on China's imperial government institutions—complete the ROC's constitutional structure, the Control Yuan and the Examination Yuan (Caldwell 2017a; Pan 1983).

When first theorizing the five-power constitution, Sun Yat-sen (孫逸仙) showed great concern over both the dangers of maladministration and the potential for one branch of government to infringe on the powers of other branches. To deal with this problem, Sun took inspiration from the censorate (yü shi 御史), an institution of the former imperial government tasked with monitoring the conduct of officials throughout the empire, investigating claims of corruption or negligence, and further empowered to arrest or impeach officials in the name of the Emperor (Walker 1947). The modernized Control Yuan (Jian cha yuan 監察院) of Sun Yat-sen was thus designed to monitor and 
investigate government officials, impeach corrupt or negligent officials, provide consent for presidential appointments, and audit the government's expenditures (Caldwell 2017b; Tung 1964). Like its predecessor, the censorate, the modern institution's primary task was to ensure the government functioned efficiently. Thus, in its early manifestation, the Control Yuan had little influence on human rights. That said, one key function that would become important in later years is the Control Yuan's ability to receive and investigate individual petitions. At the time, these petitions were not necessarily articulated as human rights claims, but were instead often claims against official corruption or negligence. In 1947, for example, the Control Yuan received over 14,000 individual petitions. During these early days of the institution, the individual petitions systems simply served as a means for the government, or at least its officials, to be monitored and ensure it maintained the rule of law and lived up to the liberal democratic principles enshrined in the constitution. This function would later become important as the individual petitions system of the Control Yuan now serves as one of the principle means for people to bring claims of human rights abuses against the government over official conduct or executive policy.

Like many other national-level institutions, the influence of the Control Yuan on government administration diminished greatly during the period of martial law (19491987). With the loss of the civil war on the mainland to communist forces, the Nationalist government transferred its operations to Taipei. Under the infamous Temporary Provisions and martial law, the majority of the liberal democratic elements of the constitution were suspended, included numerous civil and political rights (Hsieh 2005). Although the Control Yuan technically maintained its constitutional mandates, it 
was faced with the conundrum of attempting to act independently to investigate and potentially impeach officials of an authoritarian government. The martial law period saw a drastic decline in impeachment cases; yet, despite its curtailed ambit of operations, the Control Yuan did manage to perform several beneficial acts for Taiwanese citizens and in some limited ways opened the door for increased awareness of citizens' rights vis-à-vis the government (Caldwell 2017b, 757-59). First, although the total number of individual petitions declined under martial law, several thousand citizens continued to file individual petitions each year. Most of these petitions related to corruption or abuse of power by lower ranking officials. Second, prior to 1958 , citizens lacked standing to petition the Judicial Yuan for a constitutional interpretation (T. Chen 2003). To circumvent this obstacle, citizens could submit individual petitions to the Control Yuan, which did have standing to request constitutional interpretations. Between 1950 and 1990, the Control Yuan requested thirty-nine interpretations; second only to the Executive Yuan. Many of these sought clarification over the constitutionality of the KMT government's actions and policies (T. Chen 2003). Lastly, although the number of impeachments dropped, the Control Yuan increasingly relied on a politically more safe power, its power to issue corrective measures (jiu zheng 糾正). These corrective measures are often written as critiques of specific government policies deemed unconstitutional, contrary to the law or detrimental to government efficiency. The use of these corrective measures allowed the Control Yuan to subtly challenge acts and policies of the authoritarian government (Caldwell 2017b, 757-58).

Although it can be demonstrated that the Control Yuan made some minor contributions under martial law, there were still significant limitations. For example, due 
to the policies of marital law, the Control Yuan could do very little for the thousands of political prisoners or those who had suffered from coercive land expropriation practices. It lacked the capacity to actively challenge the Taiwan Garrison Command or the courtsmartial. Like the judiciary, the Control Yuan was unable to directly protect or promote the constitutional rights, and let alone the human rights of the Taiwanese (Ma 1963). Furthermore, the Control Yuan's public reputation suffered greatly during martial law. The heavily constrained supplementary elections for Control Yuan members were fraught with claims by non-KMT candidates of corruption and undue influence over its candidates and voters. Due to its constrained constitutional powers and the contested nature of its membership, when martial law was finally lifted, the Control Yuan was viewed by much of the public as an antiquated, nepotistic, and impotent branch of government. This would not seem, on the surface, to be an ideal candidate for a NHRI. However, as Taiwan democratized and human rights took center-stage in public and political debates, the Control Yuan needed to find a way to remain relevant within Taiwan's shifting constitutional landscape.

Martial law was lifted in 1987 and this was followed by the abrogation of the Temporary Provisions in 1991. To better accommodate the social and political needs of the island of Taiwan, as opposed to the full population and territory of all of China, the 1947 ROC Constitution required a great deal of revision. Through a series of constitutional reforms, the national government reinstituted elections, reinstituted the civil and political rights enshrined in the constitution, and drastically reorganized several government offices (Fell 2012). While many look positively on this era of constitutional reform as a period of citizen empowerment, strengthening of the judiciary, and 
democratization, one branch of government, the Control Yuan, did not fare well. The Control Yuan was in many ways seen as a bargaining chip among political parties, and via successive constitutional amendments, the Control Yuan found itself stripped of many of its original powers and mandates (Caldwell 2017b, 761-65). With its most powerful constitutional duties reassigned to other representative institutions, such as the Legislative Yuan, questions arose over the continued need for the Control Yuan. Such questions were made more poignant by the increasingly active judiciary which, through several significant decisions and constitutional interpretation against government action and policy, greatly improved the judicial face of human rights protection in Taiwan (Chang 2015; Yeh and Chang 2014). As support for the Control Yuan steadily waned, there arose on the horizon a contested area of government jurisdiction and potential source of new relevance for the institution: human rights protection.

In 2000, DPP candidate Chen Shui-bian (陳水扁) was elected president. This was the first time a non-KMT candidate had won the presidency since 1947. Chen and the DPP ran on a political platform that emphasized human rights promotion and protection in Taiwan. As president, Chen vowed to ratify the ICCPR and ICESCR, legislate a Human Rights Act and establish an independent human rights commission (Bowman 2012). In 2001, after much debate the DPP government issued two draft laws for consideration which outlined the structure of the proposed human rights institution and provided key mandates such as promoting human rights through education and awareness, advising the government on policies directly influencing the human rights condition in Taiwan, as well as providing investigatory powers for human rights violations (Bowman 2012, 501). This was of course heavily criticized by the KMT and 
the Control Yuan. The Control Yuan argued that providing a human rights institution with investigatory powers violated the constitution as it would infringe upon the Control Yuan's powers of investigation. To bolster its claim over a human rights protection mandate, the Control Yuan created its own Committee on Human Rights Protection. ${ }^{3}$

The Control Yuan Committee on Human Rights Protection (監察院人權保障委員 會) is comprised of nine to eleven Control Yuan members serving a one-year term (Art. 4). The Committee is tasked with bolstering human rights protection via control powers, as well as research, planning, and organization of ministerial-level agencies to protect human rights (Art. 2). To accomplish these goals, the Committee is empowered to, inter alia, discover cases of human rights abuses on its own initiative, make legislative proposals related to human rights, promote and supervise the incorporation of international human rights conventions into domestic law, liaise with NGOs and international organizations, and promote human rights protection (Art. 3). The Committee meets once per month and has jurisdiction to consider and advise on any petition or investigation of the Control Yuan which has relevance to human rights. Although the existence of this Committee supports the Control Yuan's jurisdictional claim over human rights protection, it was, however, created via internal regulations of the Control Yuan, not statutory legislation. This raises questions over whether or not such a committee could provide the Control Yuan with enough credibility to claim the title of a NHRI. ${ }^{4}$

3 Jian cha yuan ren quan bao zhang wei yuan hui she zhi bian fa 監察院人權保障委員會設置辦法 [Regulations on the Establishment of the Control Yuan Committee on Human Rights Protection] (19 May 2000, amended 19 June 2013).

4 The Paris Principles require a NHRI to be established in a constitutional or legislative text. (De Beco and Murray 2015, 41-42) 
Due in part to Taiwan's semi-presidential system, which developed from successive constitutional reforms, Chen found his administration gridlocked by a divided government (T. W. Huang 2006). The DPP held the presidency and Executive Yuan, yet the Legislative Yuan remained in firm control of the KMT. As such, most of Chen's initiatives requiring legislative approval, including the Human Rights Act, the ratification of the ICCPR/ICESCR, and the establishment of a NHRI, were all quashed by partisan politics and government gridlock (Hawang 2016). On the one hand, the inability of the government to establish an independent NHRI certainly benefited the Control Yuan as it allowed the institution via its human rights committee to retain the title of 'sole' investigator of human rights abuses, de facto. On the other hand, however, the Control Yuan found itself the political target of partisan politics under a divided government. From 2005-2008, the Control Yuan effectively ceased to exist.

As the end of the term of the Third Control Yuan approached, President Chen announced his new nominees. These nominees, however, required the consent from the KMT-dominated Legislative Yuan. Despite multiple requests, and a constitutional interpretation on the matter from the Constitutional Court, the Legislative Yuan refused to confirm the nominees (W. Chen and Hsu 2016, 161-63). For human rights protection, this certainly had a negative impact. Several thousand individual petitions were still filed each year for nearly four years, but the Control Yuan and its Committee on Human Rights Protection, lacking any members, had no way of investigating these claims (Jian cha yuan 監察院 (Control Yuan)) 2008). Thus, partisan politics seriously undermined the legitimacy of the Control Yuan's claim as the 'sole' investigator of human rights abuses in Taiwan. It wasn't until the election of KMT presidential candidate Ma Ying-jeou (馬英 
九) in 2008 that the Control Yuan was able to replenish its ranks and return to a functioning, albeit demoralized institution.

One does not readily associate Ma's administration with human rights promotion. During his presidency, many of the DPP's earlier human rights initiatives went inactive, and even the presidential Human Rights Advisory Committee "fell silent" (Ho 2014, 110-11). However, the in 2009 the Legislative Yuan approved the ratification of the ICCPR and ICESCR. This was followed later that year by the Act to Implement the ICCPR and ICESCR (2009) which embedded the provisions of these two international covenants into domestic law (Bowman 2012). With these covenants now binding on the government, there arose a need to monitor and assess the government's compliance. Ma's administration expressed an interest in establishing a NHRI to fulfil that role, but once again the Control Yuan members cited the constitutional and jurisdictional overlap that empowering such an institution. In the end, the Control Yuan's arguments won the day as constitutional and legislative changes would have required too much political capital and resources. Therefore, Taiwan did not establish an independent NHRI under Ma's administration.

Under the present DPP-led administration of President Tsai Ing-wen (蔡英文), there are once again dual calls for the abolishment of the Control Yuan and the establishment of a NHRI. While Tsai originally advocated the abolishment of the Control Yuan, more recently there seems to be a trend towards retaining the institution, but recasting its role into that of a NHRI. ${ }^{5}$ The remainder of this chapter considers what

\footnotetext{
${ }^{5}$ In her early campaigning, Tsai argued that the Control Yuan and Examination Yuan should be abolished and their remaining powers distributed among the three remaining branches (Ye 2014). However,
} 
steps are necessary to effectively transform the Control Yuan into a NHRI capable of gaining international accreditation.

\section{The Control Yuan as a NHRI}

On 24-28 July 2017, a panel of international human rights specialists met in Taipei at the Legislative Yuan to discuss Taiwan's future options for establishing a NHRI. ${ }^{6}$ Their discussions focused primarily on structural issues of establishment criteria and procedures. Overall, the panelists acknowledged that Taiwan had three viable options: to establish a fully independent NHRI; to establish a quasi-independent NHRI under the auspices of the Presidential Office; or to transform the Control Yuan into Taiwan's NHRI.

The first option, the establishment of a fully independent NHRI, was considered highly problematic. The panelists noted several significant issues that would likely impede the functionality of such an institution. As with the presidencies of Chen and Ma, the most difficult obstacle to overcome would be managing the overlapping jurisdiction of the Control Yuan. In effect, given the Control Yuan's existing jurisdiction and operations, Taiwan would be creating a multi-institutional human right protection framework. While such arrangements do exist in other jurisdictions, most scholars highlight the practical and cost-effective benefits of single institution NHRIs (Carver 2011). Furthermore, the panelists noted that they had received little attention or positive

recently she nominated several new members to the Control Yuan many of whom had extensive human rights experience (Zhong 2017).

6 The panel included international participants, Rosslyn Noonan, Sushil Pyakurel, and Agantaranansa Juanda (Covenants Watch (人權公約施行監督聯盟) 2017). 
responses from Taiwanese organizations which recommended the establishment of a standalone institution.

The second option considered the legislative establishment of a quasiindependent NHRI under the auspices of the Presidential Office. Such a practice has been common in the past and seems effective on paper. President Chen, for example, relied heavily on the presidential Human Rights Advisory Committee when his efforts to create a NHRI were thwarted. Such a practice would be particularly useful during periods of divided government. Yet such an arrangement would not likely comply with the independence criteria stipulated by the Paris Principles. NHRIs should be independent of all executive control and interference (Mertus 2012, 77). If part of the purpose of establishing the $\mathrm{NHRI}$ is to gain increased international recognition for human rights development in Taiwan, then such an institutional framework would not be the most effective choice.

For many, including the forum panelists, the Control Yuan represents the most logical and cost-effective pathway to establishing a Taiwanese NHRI (Li 2012). In its current status, however, the Control Yuan is not fully compliant with the NHRI criteria provided by the Paris Principles and GANHRI. So how does the Control Yuan measure up? What are its deficiencies? And how can these be remedied?

A first glance, the Control Yuan already meets many of the basic criteria of the Paris Principles and the subsequent benchmarks of compliance formulated by the UN, GANHRI, and other international organizations. ${ }^{7}$ These benchmarks are divided into

\footnotetext{
7 This section will utilize the structural model of assessment for NHRIs, and relies heavily on the set of foundational benchmarks formulated by Carver (2005). This assessment model has been criticized, but remains valuable for the present chapter as it directly engages the current discourse in Taiwan (Mertus 2012, 76-80).
} 
three broad categories of structure, mandate, and accountability (Carver 2005). Below I highlight a few of these benchmarks in each category to illustrate the Control Yuan's current level of compliance. Given the space constraints, I am unable to go into all the issues in detail.

\section{Structure}

The structural benchmarks of a NHRI require high levels of independence, establishment by constitutional or legislative text, transparent appointments procedures, pluralism/diversity of membership, human rights skills of membership, constructive relations with civil society, and accessibility (Carver 2005, 12-17).

The Control Yuan meets many of these requirements. It is a constitutionally established branch of the national government with a high level of independence from all other branches. Although the appointments are based on presidential nomination, there are three factors that contribute to the institution's independence. First, the nominees are not just selected by a single individual representing one party, but also require confirmation by another representative institution, the Legislative Yuan. Second, once confirmed, it is extremely difficult to impeach a Control Yuan member. This allows the Control Yuan to conduct investigations against the government without concern over retribution for their actions. Third, in order to avoid conflicts of interest, once members are confirmed they are not allowed continue their professional or civilian occupations until their term has expired. Overall, the appointments procedure is quite public as the nominees are announced via the Office of the President and the debates and confirmation hearings of the nominees by the Legislative Yuan are open and published 
in the legislative gazettes. Finally, the Control Yuan is accessible to the public via conferences, workshops, and news releases, as well as the individual petition system.

\section{Mandate}

The international benchmarks for NHRIs also require the mandate of the institution to be broad and general, including, but not limited to, the ability to comment on existing or draft laws, monitoring domestic human rights conditions, advising on compliance with international treaty obligations, educating in the field of human rights, receiving complaints, and monitoring government compliance with $\mathrm{NHRI}$ issued advice (Carver 2005, 17-22).

Again, the Control Yuan meets many of the basic benchmarks for compliance. The Control Yuan has the capacity to discuss and recommend legislation or specific legislative changes that fall within its jurisdiction. The primary duty of the Control Yuan is monitoring the government (Constitution Art. 90) and it has a wide range of constitutionally enshrined investigatory powers. Furthermore, with the establishment of the Committee for Human Rights Protection and its related functions, the Control Yuan is now required to monitor and make recommendations related to the government's compliance with the ICCPR and ICESCR. Since 2000, the Control Yuan receives over 12,000 individual petitions from the public each year (W. Chen and Hsu 2016, 161). The vast majority of these petitions relate specifically to claims of human rights abuses.

One significant gap in the Control Yuan's mandate is the private sector. As mentioned above, the Control Yuan was originally designed to monitor the government. Although it now has a human rights mandate, its constitutionally provided powers are limited to investigations of the government, specifically the Executive, Judicial, and 
Examination Yuans. The Control Yuan does not have the authority to use its investigatory powers against private entities. Therefore, in its present status, the Control Yuan only possesses a partial investigatory and quasi-judicial mandate (De Beco and Murray 2015).

\section{Accountability}

The Paris Principles and subsequent GANHRI accreditation criteria also require a NHRI to have a high level of public accountability (De Beco and Murray 2015, 141). This accountability is manifest in public reports of the institution, including reports on budgets, institutional activities, and advice/recommendations to the government (Carver 2005, 23). Here too, the Control Yuan meets many of the international benchmarks. The Control Yuan produces numerous public reports each year ranging from monthly gazette issues which include specific cases and communications with other branches of government, to annual reports on human rights. All of the Control Yuan reports are available to the public in print format, and most can be found online for free download at the Control Yuan website. ${ }^{8}$

\section{Reforming for Compliance?}

On the surface, the Control Yuan not only seems like the ideal candidate for a Taiwanese NHRI, but also appears to comply with many of the basic requirements of the international community. And yet, there are limitations to its compliance that could seriously jeopardize its ability to gain international accreditation should the Control Yuan be submitted for review in its current state. In the recent NHRI forum, mentioned above,

\footnotetext{
${ }^{8}$ Control Yuan of the Republic of China (Taiwan), www.cy.gov.tw
} 
the panelists produced a list of suggestions for how the Control Yuan could be 'repackaged' into a NHRI. These include, among other things:

- Appointment of personnel should be public and engaged with civil society

- Nominees should have human rights qualifications and experience

- Membership should reflect the diversity of Taiwanese society

- Investigative powers should have jurisdiction over public and private claims

- Increased communication with Taiwanese civil society

- Should be responsible to the Legislative Yuan

Such proposals, if acted upon, would certainly heighten the Control Yuan's conformity with the Paris Principles; however, to convert the Control Yuan into a NHRI along the lines suggested by the forum panelists would require some significant, and in some cases nearly insurmountable alterations to Taiwan's constitutional structure as well as numerous revisions to key legislation related to the Control Yuan. In this section, I will highlight a few of the substantial obstacles to reforming the Control Yuan by examining the necessary steps involved in altering the appointments process. In doing so, I am not arguing against the possibility of transforming the Control Yuan into a NHRI, but I am merely articulating the significant obstacles which must be overcome in order to make the Control Yuan fully compliant with the Paris Principles.

\section{Appointments}

According to the Additional Articles of 1947 ROC Constitution the Control Yuan shall consist of 29 members appointed for six years, with nominees chosen by the president and confirmed by the Legislative Yuan (Additional Articles, Art. 7). 
Furthermore, the Organic Law of the Control Yuan ${ }^{9}$ requires members to be at least 35 years of age and meet one of a series of requirements such as, a period of civil service in provincial or national government, a distinguished career in a judicial role or as a university professor, or honesty and integrity with extensive political experience (Art. 31). Such requirements do allow for great diversity in the educational and career backgrounds of appointees.

The NHRI forum panelists, however, highlighted several problematic elements of the Control Yuan appointment process that would need to be revised before the institution complies with the Paris Principles. It was noted that the Control Yuan membership should be considered via an open and public process, in which all stakeholders may voice their opinions. This could include requirements to publicize vacancies (for each Term), to mandate specific characteristics and human rights backgrounds for applicants, and to promote public consultation and participation in the application, screening, and appointment process (De Beco and Murray 2015, 89).

I do agree with the suggestions of the forum panelists; however, to accommodate such changes to the Control Yuan the constitution and several pieces of legislation would need to be altered. For example, at present, the constitution provides that nominees are chosen at the president's discretion without the need for public consultation (Additional Articles, Art. 7). To alter the nomination process, one would necessarily be required to revise the constitution. In Taiwan, this has become an extremely difficult process. With the introduction of the 2005 Additional Articles, any constitutional revision requires a high level of bi-partisan cooperation and extremely

\footnotetext{
9 Jian cha yuan zu zhi fa 監察院組織法 [Organic Law of the Control Yuan] (31 March 1947, last amended 19 May 2010).
} 
high level of direct popular support. For a constitutional revision to occur, it must first be passed by three-fourths of the Legislative Yuan members present at a meeting attended by at least three-fourths the total membership. Then it must pass a public referendum in which the total number of valid votes in favor exceeds one half the total number of electors (Additional Articles, Art. 12). All previously held public referendums have failed due to low voter turnout. Given the turbulent political climate in Taiwan and the necessary public support, it is doubtful that the such a constitutional change could be effected.

On the other hand, however, there is potential for altering membership requirements via statutory changes. One could 'simply' revise the Organic Law of the Control Yuan and fulfil many of the Paris Principles' criteria for appointment. For example, to increase diversity and pluralism of membership, Article 3-1 could provide that underrepresented groups hold a reserved number of seats, such as disabled persons, indigenous peoples, and women. This would fulfil the Paris Principles requirements that membership of a NHRI should reflect the diversity of Taiwanese society (De Beco and Murray 2015, 67-80). Furthermore, in revising the same article, one could establish criteria for membership which includes requirements for human rights experience. This could be gained through a career in activism, a judicial or legal career dealing with human rights cases, or an academic background in human rights teaching or promotion. By narrowing the eligibility criteria and including a greater emphasis on a) diversity and b) human rights experience, statutory changes could refine the acceptable applicant pool available to the president. This would not necessarily create a requirement that the president seeks nominees on the basis of 
consultations, but given the legislative majority currently held by the DPP, statutory changes of this nature would certainly be possible. By no means easy, but not impossible.

While this demonstrates the potential for providing a structural framework that would comply with the Paris Principles, the old dangers of Taiwan's hybrid semipresidential system would remain. In echoing the warnings of Carver (2005), establishing a fully compliant NHRI does not necessarily correlate to the effective promotion and protection of human rights. In order to be effective, a NHRI must be designed with the local social and political contexts in mind.

Unless the constitution were to be fully revised, the Control Yuan would always be a potential victim of government gridlock under a divided government. Just a Chen Shui-bian was unable to have his Control Yuan nominees confirmed by a KMT-led Legislative Yuan, so too could a future president find his or herself in a similar position. Yet, even in a period of unified government, for example, when the KMT held both the presidency with Ma Ying-jeou and the legislative majority, only eighteen of the president's Control Yuan nominees were confirmed (Lin 2014). Thus, instead of the normal twenty-nine members, since Ma's administration the Control Yuan has been functioning with a severely limited capacity. For human rights protection, this has significant ramifications as the Control Yuan. For example, in 2016, the Control Yuan received 13,615 individual petitions of which $11,307(83 \%)$ specifically related to human rights claims (Control Yuan 2017, 257). The Control Yuan conducted a total of 273 investigations in 2016, and of those $114(41.8 \%)$ were human rights cases (Control Yuan 2017, 257). Yet, with eleven members not confirmed, the Control Yuan has limited 
time and resources to adequately review and investigate the increasing volume of human rights related petitions its receives each year. Simply increasing diversity and selection criteria via statutory revision would not necessarily solve all the Control Yuan's problems. Nor would such changes necessarily benefit the protection and promotion of human rights in Taiwan.

\section{Retain, Reform, or Retire: The Future of the Control Yuan and its Role in the Protection and Promotion of Human Rights in Taiwan}

In many ways, the discussion above leads to the all-important question of, whither the Control Yuan? Should the institution be retained as it currently exists, reformed into a NHRI, or perhaps retired altogether? The answer to these questions impacts not just the Control Yuan's role as a core component of Taiwan's constitutional structure, but also its continued role as part of Taiwan's developing human rights protection and promotion framework.

At present, there is no simple answer. The first option is to simply retain the Control Yuan in its current form and with its current mandate. Yet, what would this option mean for the advancement of human rights in Taiwan? Echoing the criticism of the 2017 human rights review committee, Taiwan would still lack a NHRI that complies with the Paris Principles. The Control Yuan would still be subject to the negative effects of the semi-presidential system that could severely limit its ability to effectively protect human rights. Furthermore, despite its Committee on Human Rights Protection, as several scholars have noted, the Control Yuan does not fully comply with the Paris Principles. In its current form, should the Control Yuan be submitted as a NHRI for international accreditation, it would certainly not receive an ' $A$ ' rating, and it is 
questionable as to whether it would receive a 'B' rating. An unaltered Control Yuan and a lack of a dedicated NHRI would not, therefore, likely prove to be a viable option for developing the Taiwanese human rights landscape.

The second option of substantially altering the Control Yuan would of course be the most beneficial pathway. As already mentioned, this would necessitate a great deal of constitutional revision requiring public support and cross-party cooperation. Yet, one mustn't focus too closely on matching every single aspect of the Paris Principles. A great deal of attention must be paid to the actual social and political domestic issues that the NHRI must confront, engage, and contend with. As already shown the Control Yuan currently suffers considerable downsides as an NHRI that go beyond the compliance issues mentioned by other scholars. Simply altering the appointments and eligibility requirements to provide greater pluralism and diversity, as well as public engagement would not enough to ensure the Control Yuan functions effectively as a NHRI. The highly volatile political climate, and the way in which party politics play out within Taiwan's semi-presidential system, have the potential to seriously impede the Control Yuan's functionality. To transform into a successful and effective NHRI, the Control Yuan would certainly require not just a statutory overhaul, but also a serious constitutional revision of its appointment process. Such changes would have significant implications for the constitutional structure of Taiwan, and would be very difficult to carry out.

The final option is to retire the Control Yuan altogether. The DPP have long advocated for the abolishment of this institution, and even president Tsai has in the past contemplated simply not re-appointing any further members once the current term 
expires. Yet, although the Control Yuan suffered a great downturn in public opinion since the martial law era, there exists little support for fully abolishing the institution as was done with the National Assembly in 2005. Furthermore, given the current difficulties of constitutional reform in Taiwan, the possibility of altering the constitution in such a drastic fashion is now highly unlikely. For decades, the Control Yuan has fought to preserve its role in human rights protection in Taiwan. Although it has many problems, by shuttering the Control Yuan, Taiwan would leave an institutional void for human rights protection and promotion that would need to be immediately filled.

The futures of the Control Yuan and for human rights in Taiwan are inextricably linked. Given the options for reform and their requirements of bi-partisan cooperation and public support, the choice of direction forward is a matter for the Taiwanese people to determine. 


\section{BIBLIOGRAPHY}

Bowman, Daniel. 2012. "Righting the Wrongs of the Past? The Human Rights Policies of Chen Shui-Bian and Ma Ying-Jeou." In Taiwan since Martial Law: Society, Culture, Politics, and Economy, edited by David Blundell, 485-526. Taipei: Shung Ye Museum of Formosan Aborigines.

Caldwell, Ernest. 2017a. "Chinese Constitutionalism: Five-Power Constitution." In Max Planck Encyclopedia of Comparative Constitutional Law, edited by Rainer Grote, Frauke Lachenmann, and Rüdiger Wolfrum, ONLINE. Oxford: Oxford University Press.

. 2017b. "Widening the Constitutional Gap in China and Taiwan: Histor, Reform, and the Transformation of the Control Yuan." University of Illinois Law Review 2017 (2): 739-66.

Carver, Richard. 2005. "Assessing the Effectiveness of National Human Rights Institutions." International Council on Human Rights Policy. . 2011. "One NHRI or Many? How Many Institutions Does It Take to Protect Human Rights? Lessons from the European Experience." Journal of Human Rights Practice 3 (1): 1-24.

Chang, Wen-Chen. 2015. "Courts and Judicial Reform in Taiwan: Gradual Transformations towards the Guardian of Constitutionalism and Rule of Law." In Asian Courts in Context, edited by Wen-Chen Chang and Jiunn-rong Yeh, 14382. Cambridge: Cambridge University Press.

Chen, Tsung-fu. 2003. "Democracy and Rule of Law in Taiwan: The Judiciary's Authority and Credibility." RCTED Working Paper Series No. 2003-0006, 1-18.

Chen, Weitseng, and Jimmy Chia-shin Hsu. 2016. "Horizontal Accountibility and the Rule of Law." In Taiwan's Democracy Challenged: The Chen Shui-Bian Years, edited by Yun-han Chu, Larry Diamond, and Kharis Templeman, 145-71. Boulder: Lynne Rienner.

Control Yuan. 2017. Jian Cha Bao Gao Shu: Zhong Hua Min Guo 105 Nian 監察竍告書: 中華民國 105 年 [Annual Report of the Control Yuan, 2016]. Taipei: Control Yuan.

Covenants Watch (人權公約施行監督聯盟). 2017. “Guo Ji Zhuan Jia Lai Tai Jin Xing Guo Jia Ren Quan Wei Yuan Hui Ping Gu Ren Wu Chu Bu Sheng Ming 國際專家 來台進行國家人權委員會評估任務初步聲明 [Preliminary Report by International Specialists Assessing the Progress of a National Human Rights Institution]." Ren Quan Gong Yue Shi Xing Jian Du Lian Meng 人權公約施行監督聯盟 (Convenants Watch). July 28. http://covenantswatch.org.tw/2017/07/28/preliminary_statement/.

De Beco, Gauthier, and Rachel Murray. 2015. A Commentary on the Paris Principles on National Human Rights Institutions. Cambridge: Cambridge University Press. Fell, Dafydd. 2012. Government and Politics in Taiwan. 2nd ed. London: Routledge. Hawang, Shiow-duan. 2016. "Executive-Legislative Relations under Divided Government." In Taiwan's Democracy Challenged: The Chen Shui-Bian Years, 
edited by Yun-han Chu, Larry Diamond, and Kharis Templeman, 123-44. Boulder: Lynne Rienner.

Ho, Ming-sho. 2014. "The Resurgence of Social Movements under the Ma Ying-Jeou Government: A Political Opportunity Structure Perspective." In Political Changes in Taiwan under Ma Ying-Jeou: Partisan Conflict, Policy Choices, External Constraints and Security Challenges, edited by Jean-Pierre Cabestan and Jacques deLisle, 100-119. London: Routledge.

Hsieh, Cheng-tao. 2005. Zhonghua Minguo Xiuxian Shi 中華民國修罳史. 2nd ed. Taipei: Polis.

Huang Song-lih (黄嵩立). 2014. “Gong min tuan ti dui guo jia ren quan wei yuan hui zhi yi jian 公民團體對國家人權委員會之意見 [The Opinions of Taiwanese Civil Society Organizations on a National Human Human Rights Commission]." Taiwan ren quan xue kan 台灣人權學刊 [Taiwan Journal of Human Rights] 2 (3): 81-95.

Huang, Thomas Weishing. 2006. "The President Refuses to Cohabit: SemiPresidentialism in Taiwan." Pacific Rim Law \& Policy Journal 15 (2): 375-402. International Group of Independent Experts. 2013. "Review of the Initial Report of the Government of Taiwan on the Implementation of the International Human Rights Covenants: Concluding Observations and Recommendations Adopted by the International Group of Independent Experts." Taipei.

http://www.humanrights.moj.gov.tw/mp205.html. 2017. "Review of the Second Report of the Government of Taiwan on the Implementation of the International Human Rights Covenants: Concluding Observations and Recommendations Adopted by the International Group of Independent Experts." Taipei. http://www.humanrights.moj.gov.tw/mp205.html.

Jian cha yuan 監察院 (Control Yuan)). 2008. Te Xu Yun Zhuan Yu Deng dai-Jian Cha Yuan Mei You Jian Cha Wei Yuan Qi Jian Gong Zuo Ji Yao 特續運轉與等待 ——監察院沒有監察委員期間工作輯要. Taipei: Control Yuan.

Li Nien-tsu (李念祖). 2012. "Lun yi Ba Li yuan ze yu jian cha yuan she zhi guo jia ren quan wei yuan hui 論依巴黎原則於監察院設置國家人權委員會 [Establishing a National Human Rights Commission within the Control Yuan in Accordance with the Paris Principles]." Taiwan ren quan xue kan 台灣人權學刊 [Taiwan Journal of Human Rights] 1 (3): 125-43.

Liao, Fort Fu-te. 2001. "Establishing a National Human Rights Commission in Taiwan: The Role of NGOs and the Challenges Ahead." Asia-Pacific Journal on Human Rights and the Law 2 (2): 90-109.

Lin Nan-sen (林楠森). 2014. "Taiwan Jian cha wei yuan ti ming ren yu shi ren wei huo tong guo 台灣監察委員提名人逾十人未獲通過.” BBC Chinese Edition. July 29. www.bbc.com/zhongwen/trad/china/2014/07/140729_tw_control_yuan_norminati ons.

Ma, Herbert H.P. 1963. "Chinese Control Yuan: An Independent Supervisory Organ of the State." Washington University Law Review, no. 4: 401-26.

Mertus, Julie. 2012. "Evaluating NHRIs: Considering Structure, Mandate, and Impact." In Human Rights, State Compliance, and Social Change: Assessing National Human Rights Institutions, 74-92. Cambridge: Cambridge University Press. 
Pan, Wei-tung. 1983. The Chinese Constitution: A Study of Forty Years of ConstitutionMaking in China. Westport: Hyperion Press.

Su Yiu-chen (蘇友辰). 2002. "Lun guo jia ren quan wei yuan hui de jiao se yu di wei 論 國家人權委員會的角色與地位 [The Role and Status of a National Human Rights Commission]." Guo jia zheng ce ji kan 國家政策季刊 [Journal of National Policy] $1(2): 1-32$.

Tung, William L. 1964. The Political Institutions of Modern China. The Hague: Martinus Nijhoff.

Vile, M.J.C. 1998. Constitutionalism and the Separation of Powers. 2nd ed. Indianapolis: Liberty Fund.

Walker, Richard L. 1947. "The Control System of the Chinese Government." The Far Eastern Quarterly 7 (1): 2-21.

Wei Chien-feng (魏千峯). 2012. "Women wei shen ma xu yao guo jia ren quan wei yuan hui? 我們為甚麼需要國家人權委員會? [Why We Need a National Human Rights Commission?]." Taiwan ren quan xue kan 台灣人權學刊 [Taiwan Journal of Human Rights] 1 (3): 97-123.

Ye Su ping (葉素萍). 2014. “Tsai Ing-wen pan bu bu ti jian wei 蔡英文盼不補監委 [Tsai Ing-wen hopes not to supplement Control officials]." Da Ji Yuan 大紀元 [Epoch Times]. July 30. www.epochtimes.com/b5/14/5/30/n4212718.

Yeh, Jiunn-rong, and Wen-Chen Chang. 2014. "A Decade of Changing Constitutionalism in Taiwan: Transitional and Transnational Perspectives." In Constitutionalism in Asia in the Early Twenty-First Century, edited by Albert H.Y. Chen, 141-68. Cambridge: Cambridge University Press.

Zhong Lihua (鍾麗華). 2017. “Jian wei bu ti ming ren: zuo hao [mo dai jian wei] xin li zhun bei 監委補提名人:做好「末代監委」心理準備 [Supplementary Control Nominees: Prepared to Serve as 'Final Control Officials]." Zi you shi bao dian zi bao 自由時郝電子般 [Liberty Time Digital Edition. March 2. http://m.Itn.com.tw/news/politics/breakingnews/1991307. 